UDC 371.134:338.48

DOI: https://doi.org/10.37320/2415-3583/14.10

Melnyk Alona
Head and Profersor

Kyiv National University of Technology and Design ORCID: https://orcid.org/0000-0002-4051-3033

Budiakova Olena

Senior Lecturer at the Department of Business Economics and Tourism, Kyiv National University of Technology and Design ORCID: https://orcid.org/0000-0001-6028-2650

Kisilov Vadim

Master at the Department of Business Economics and Tourism, Kyiv National University of Technology and Design

\title{
FEATURES OF TECHNOLOGY TRANSFER IN THE CONDITIONS OF INTEGRATION
}

Increasing the competitiveness of both the national and regional economy requires technological re-equipment of most Ukrainian enterprises. To do this, applied science must be developed, which in the future can be commissioned to develop the necessary technologies, as the leading position in the market is occupied by companies that have the ability to produce fundamentally new products. Technology transfer is an important and integral part of the innovation process. Public laboratories, research institutes, universities are puzzled by the applied technological use of their research. In today's world, the strategy of survival and development of society, countries are based mainly solely on the pursuit of leadership in various fields. To create new models, technologies and products, as well as their transformation in the world.

Key words: technology transfer, scientific and technical cooperation, innovative economy, international integration, national innovation system.

JEL classification: F02, E22, O32

Formulation of the problem. In Ukraine, the concept of "technology transfer" appeared relatively recently. In this phrase, "transfer" means to deliver, and "technology" in this context means both the results of research and development, and innovative product. Technology transfer is the process of transferring the results of research and development, knowledge for any use. Technology transfer is the main form of innovation promotion from the development stage to commercial implementation. This concept includes all sorts of ways to turn an idea into a commercial product: the transfer of patents, technical documentation, exchange of scientific developments, the creation of joint ventures and others. At the present stage of development of the world economy technology transfer is one of the sources of economic independence, as it provides economic entities with strategic opportunities in the development of the domestic market and new growing industries, borrowing and adapting the achievements of more developed countries, integration into transnational infrastructure of world markets [1, p. 30]. Taking into account the potential of each business entity, its approach to technology transfer in relation to the organization of production and innovation policy should be developed.

According to statistics, the import of technology in Ukraine is much higher than its exports. For example, this applies to food production, pulp and paper production, publishing and printing, chemical production, production of other non-metallic mineral products, metallurgy. It follows that one of the priority areas of state development should be technology transfer within Ukraine. As mentioned above, for innovative development and development of technology transfer in Ukraine, it is necessary to increase the intensity of exchange of knowledge-intensive products. According to estimates, innovation activity in the field of technological innovation is one of the key indicators of innovation, which characterizes the potential of technological modernization and innovative development of Ukraine's economy. In most areas of the economy, this activity is low both due to the economic crisis and due to the following reasons:

- scientists-developers, as a rule, do not know the peculiarities of the market and can hardly imagine how their scientific results can be transformed into a market product;

- economic agents of the market (managers of companies) are practically unfamiliar with the nature of modern science, the structure and the most important areas of its activities, breakthrough achievements. They cannot always judge the reliability of the scientific results proposed for implementation and their technological efficiency;

- the state (represented by politicians and technical experts), called to establish rules for technology transfer, has little idea of the real atmosphere of life of scientific laboratories, conditions of research and development of technologies, possible consequences of implementing legislation for the production of scientific knowledge and its commercialization.

It can be concluded that Ukraine now has a lot of problems (for example, weak regional infrastructure) that hinder the implementation of new solutions. At the same time, it should be noted that the field of technology transfer, despite many limiting factors, is beginning to develop in Ukraine. Such factors include: the inability of technology transfer actors to act independently, and the inability to 
assess the need and effectiveness of innovation, and the inefficiency of the creation of research centers. Of course, it is also necessary to keep in mind the financial component of the introduction of technology in the enterprise, the ability of the organization to finance technology through cheap sources of borrowed capital and at the same time benefit. But there are also advantages, such as, for example, highly educated staff with knowledge and experience in creating and applying technologies in various sectors of the economy, in many of which Ukraine is a leader.

Analysis of recent research and publications. Scientific and methodological approaches to the organization of technology transfer have been studied by many scientists. We can mention V. Yelnikov, E. Geiger, A. Petrunenkov, P.Romer, A. Folomyev, N. Fonstein, A. Shpak, Y. Yakovets, and others. However, their work is devoted mainly to the theoretical aspects of the development of various forms of technology transfer, while the issues of commercialization of intellectual property in the national economy require additional research. P. Mykytyuk and others also addressed the definition of innovative development in their works. From their point of view, "innovative development involves the use of real innovation opportunities to achieve goals in a number of areas - mobilization and improvement of innovation potential and its main resource - human capital, improving the innovation climate" [2].

Setting objectives. The purpose of the study is to analyze the features and problems of technology transfer in terms of integration.

Presentation of the main research material. According to the Law of Ukraine "On Innovation", "innovations are newly created (applied) and (or) improved competitive technologies, products or services, as well as organizational and technical solutions of production, administrative, commercial or other nature that significantly improve the structure and quality production and (or) social sphere, and innovation is an activity that aims to use and commercialize the results of research and development and leads to the release of new competitive goods and services [3].

The negative consequences of the crisis in the economy of Ukraine lead to a significant destruction of the scientific and technological structure of our state. The conditions for conducting research and development and introducing new modern technologies into production have noticeably become more complicated. The demand for the results of scientific and technical activities today is very small. The rate of investment support for endangered technological systems, inevitably leads to higher prices for new equipment, outpacing the growth of its productivity, stimulated not only inflationary trends associated with rising cost inflation, but also structural distortions caused by faster development of industries. Note, that the rise in price of products, outpacing the growth of its consumer properties, to some extent was also a consequence of prevailing in the team economy management system (in particular, the cost approach to assessing the activities of enterprises). However, the decisive role belonged to the technical and economic policy, which gives priority to technologies in the last phase of the life cycle. Currently, companies are devoting significant resources to the modernization of industry, in the modern equipment of research and development centers of higher education. However, indicators of innovation activity, the number of applied developments and technologies continue to lag behind the world level $[4 ; 5]$.

From time to time, attempts are made to convince the general public that a reasonable compromise needs to be found between investing in economic stabilization and spending on the social sphere, ie combining the achievement of these two difficult-to-reconcile goals. However, despite all the existing difficulties, Ukraine still not only retains significant scientific and technological potential, but also has opportunities to ensure its development. The lack of technology transfer in Ukraine as a system creates favorable conditions for selling our latest technologies for nothing abroad, which, in turn, is the reason for the reduction of foreign investment and in no way contributes to gaining much-needed experience of international cooperation. Lack of experience in technology transfer or unwillingness to acquire it over time will lead to the fact that due to the obsolete or underdeveloped industrial base of goods and services of mass demand will be of a very low quality, production costs will not pay off, exports will become problematic, imports will disappear, which will naturally affect the international relations.

If we briefly summarize the previously published analytical materials, we can draw the following conclusions. Over the past decade, Ukrainian science has suffered significant losses. Total budget funding for research has decreased from $0.82 \%$ of GDP in 2012 to $0.34 \%$ in 2021 and today the cost per Ukrainian researcher is not much more than 2 thousand USD, compared to 195 thousand USD, 172 thousand in France, 142 thousand in Japan and 8 thousand - in Russia. During the same years, the number of specialists directly engaged in research and development decreased from 295 thousand people to about 120 thousand, several thousand specialists emigrate from the country annually (including more than 700 doctors and candidates of science) [8, p. 20-28].

In most countries of the world, the source of funding for innovation is budget funds, in Ukraine budget funds are allocated for the development of innovation in the minimum amount (Table 2).

In 2018, expenditures on innovations were mainly made at the expense of own funds (over $88.2 \%$ of total financing), loans from budget funds $(5.2 \%)$, other sources $(5.6 \%)$, foreign investors $(0.9 \%)$. During 2018, enterprises spent 12.2 billion UAH on innovations. Funding for innovation from the state budget 19 was carried out at the level of 5.2\% and more (with the exception of 2010-2014 and 2017), and since 2000 less than $1 \%$, this is an indicator of the state's passivity to innovation. This rather negative trend forces Ukrainian enterprises to use other external resources to innovate. Among the researchers who consider this problem A. Muliakova-Bochi can be distinguished. She notes that in foreign countries, the technological balance includes information on income from the possession of technological assets under the protection of industrial property law, which are generated mainly through agreements related to patents, inventions, etc. [10].

In 2000-2014, the state determined that the priority of further development of the country should be the restructuring of industry and the establishment of Ukraine as a high-tech state. This strategic course was based on the development and restructuring of most economic sectors, the renewal of the technological industry and the widespread 
Table 1 - Assessment of technological development of Ukraine according to international ratings

\begin{tabular}{|c|c|c|c|c|c|c|c|c|}
\hline № & Indicator & $\begin{array}{c}\text { Target } \\
\text { landmark }\end{array}$ & $\begin{array}{l}\text { Leader country } \\
\text { indicator }\end{array}$ & $\begin{array}{c}\text { Indicator } \\
\text { of Ukraine }\end{array}$ & $\begin{array}{l}\text { Rating } \\
2012- \\
2013\end{array}$ & $\begin{array}{l}\text { Rating } \\
\text { 2013- } \\
2014 \\
\end{array}$ & $\begin{array}{c}\text { Rating } \\
\text { 2014- } \\
2015 \\
\end{array}$ & $\begin{array}{l}\text { Rating } \\
\text { change }\end{array}$ \\
\hline 1. & IGC & 7.0 & 5.7 Switzerland & 4.14 & 73 & 84 & 76 & +8 \\
\hline 1.9 & $\begin{array}{l}\text { Sub-index of technological } \\
\text { readiness }\end{array}$ & 7.0 & 6.36 Luxembourg & 3.5 & 81 & 94 & 85 & +9 \\
\hline 1.9 .1 & $\begin{array}{l}\text { Introduction of technologies at } \\
\text { the company level } \\
\text { Foreign direct investment and } \\
\text { technology transfer }\end{array}$ & 7.0 & 6.2 Iceland & 4.2 & 69 & 100 & 100 & 0 \\
\hline 1.9 .2 & $\begin{array}{l}\text { Foreign direct investment and } \\
\text { technology transfer }\end{array}$ & 7.0 & 6.4 Ireland & 3.7 & 109 & 131 & 127 & +4 \\
\hline 1.9 .3 & Internet users, $\%$ & $100 \%$ & 96.5 Ісландія & 41.8 & 88 & 93 & 82 & +11 \\
\hline 1.9 .4 & $\begin{array}{l}\text { Number of broadband Internet } \\
\text { subscribers (per } 100 \text { people) }\end{array}$ & The higher & 43.0 Switzerland & 8.8 & 69 & 71 & 68 & +3 \\
\hline 1.9 .5 & $\begin{array}{l}\text { Internet bandwidth } \\
\text { (kbps for 1 Internet user }\end{array}$ & The higher & 6445.8 Luxembourg & 52.9 & 86 & 84 & 50 & +34 \\
\hline 1.9 .6 & $\begin{array}{l}\text { Number of mobile phones } \\
\text { (per } 100 \text { inhabitants) }\end{array}$ & The higher & 135.1 Singapore & 5.4 & 81 & 94 & 107 & -11 \\
\hline 1.9 .7 & $\begin{array}{l}\text { Availability of the latest } \\
\text { technologies }\end{array}$ & 7.0 & 6.6 Finland & 4.1 & 80 & 106 & 113 & -7 \\
\hline 2. & Global Innovation Index & 100 & 64.78 Switzerland & 36.26 & 62 & 71 & 63 & +8 \\
\hline 2.1 & $\begin{array}{l}\text { Subindex of available resources } \\
\text { and conditions for innovation }\end{array}$ & 100 & 73.6 Singapore & 38.15 & 78 & 83 & 88 & -5 \\
\hline 2.2 & $\begin{array}{l}\text { Subindex of results of } \\
\text { implementation and } \\
\text { implementation of innovations }\end{array}$ & 100 & $\begin{array}{l}63.11 \\
\text { Switzerland }\end{array}$ & 34.37 & 47 & 58 & 46 & +12 \\
\hline
\end{tabular}

Source: compiled by the authors on the basis [6;7]

introduction of advances in science and technology. This was due to the fact that in those years Ukraine had significant opportunities for economic development in the scientific and technological direction. The total number of researchers in Ukraine is almost 200 thousand people, including 4.1 thousand doctors of sciences, 18.9 thousand candidates of sciences [11]. Despite some reduction in scientific staff, Ukraine remains among the developed countries in Europe in terms of economic saturation of scientific staff. In recent years, a number of important measures have been taken at the state level to improve the state science and technology policy. The Verkhovna Rada approved a new Concept of Scientific, Technological and Innovative Development of Ukraine [12].

Within the framework of the mechanism of innovative development, it is represented by the implementation of the following stages:

1. On the verge of creating innovations in accordance with these areas. In order to intensify the creation of innovations, it is necessary to create a device to stimulate scientists to form a relevant research topic needed by mass markets; to harmonize national characteristics of statistical data with the European scientists; to guarantee the creation of educational materials on entrepreneurship and innovation, economic literacy and protection of intellectual property.

2. At the border of innovation transfer, it is necessary to create a Roadmap for the implementation of the Sustainable Development Goals; start a communication device of technology platforms, where business and government have every chance to become potential customers of innovations, and scientists, students, inventors offer innovative solutions, which are then scaled and become the basis for personal innovation business. Creating favorable conditions for bringing innovations to commercial use, in particular through the development of startups.

3. In order to establish mass production, monetary mechanisms should be aimed at offering direct state support to manufacturing enterprises, when the government is considered a customer of products while increasing the selection of these plans and creating devices for commercialization of developments to selectively reimburse the state costs and approval of authors.

4. Solving legal problems related to defense and used intellectual property, especially (but not only) the creation of the state budget from used funds.

5. Establishing links between the Ukrainian innovators and partners (business and government representatives) potentially interested in commercializing their innovations.

Conclusions. Ukraine's presence in the international market of high-tech products and in international technology transfer is excessively low. The domestic and foreign economic situation is complicated by the technological complexity of the economy, insufficient attention to the problem of building a national innovation system. A necessary prerequisite for using this experience is the creation of an appropriate innovation infrastructure. These are, in particular, specialized research centers and innovation firms that would ensure the transformation of new promising scientific ideas into product and technological innovations, a new legal framework that encourages innovative entrepreneurship and guarantees the protection of intellectual property rights; science (innovation) parks; a developed network of venture funds 
Table 2 - Sources of funding for innovation in Ukraine

\begin{tabular}{|c|c|c|c|c|c|c|c|c|c|}
\hline \multirow{2}{*}{ Years } & \multirow{2}{*}{\begin{tabular}{c} 
Total \\
amount of \\
expenses, \\
\cline { 3 - 10 }
\end{tabular}} & \multicolumn{9}{|c|}{ own } & \multicolumn{2}{|c|}{ state budget } & \multicolumn{2}{c|}{ foreign investors } & \multicolumn{2}{c|}{ other sources } \\
\cline { 3 - 10 } & mIn. UAH & mIn.UAH & $\begin{array}{c}\text { Propor- } \\
\text { tion \% }\end{array}$ & mIn. UAH & $\begin{array}{c}\text { Propor- } \\
\text { tion \% }\end{array}$ & mln. UAH & $\begin{array}{c}\text { Propor- } \\
\text { tion \% }\end{array}$ & mIn. UAH & $\begin{array}{c}\text { Propor- } \\
\text { tion \% }\end{array}$ \\
\hline 2000 & 1757.1 & 1399.3 & 79.6 & 7.7 & 0.4 & 133.1 & 7.6 & 217 & 12.3 \\
\hline 2005 & 5751.6 & 5045.4 & 87.7 & 28.1 & 0.5 & 157.9 & 2.7 & 520.2 & 9.0 \\
\hline 2010 & 8045.5 & 4775.2 & 59.4 & 87 & 1.1 & 2411.4 & 30.0 & 771.9 & 9.6 \\
\hline 2011 & 14333.9 & 7585.6 & 52.9 & 149.2 & 1.0 & 56.9 & 0.4 & 6542.2 & 45.6 \\
\hline 2012 & 11480.6 & 7335.9 & 63.9 & 224.3 & 2.0 & 994.8 & 8.7 & 2925.6 & 25.5 \\
\hline 2013 & 9562.6 & 6973.4 & 72.9 & 24.7 & 0.3 & 1253.2 & 13.1 & 1311.3 & 13.7 \\
\hline 2014 & 7695.9 & 6540.3 & 85.0 & 344.1 & 4.5 & 138.7 & 1.8 & 672.8 & 8.7 \\
\hline 2015 & 13813.7 & 13427.0 & 97.2 & 55.1 & 0.4 & 58.6 & 0.4 & 273.0 & 1.9 \\
\hline 2016 & 23229.5 & 22036.0 & 94.6 & 179.0 & 0.8 & 23.4 & 1.0 & 991.1 & 4.3 \\
\hline 2017 & 9117.5 & 7704.1 & 84.5 & 227.3 & 2.5 & 107.8 & 1.2 & 1078.3 & 11.8 \\
\hline 2018 & 12180.1 & 10742.0 & 88.2 & 639.1 & 5.2 & 107.0 & 0.9 & 692.0 & 5.6 \\
\hline
\end{tabular}

Source: compiled by the author based on the source [9]

and the necessary tax benefits; the stock market of small implementing firms and other elements of innovation infrastructure have not received sufficient development in Ukraine yet, but have proven themselves well in the practice of industrialized countries.

Effective technology transfer to the national economy and the internationalization of innovation are constrained by a number of factors, in particular: low innovation demand in the national economy; lack of a sufficient number of small high-tech enterprises; weak connection in the subsystem "education-science-production"; lack of benefits for innovative enterprises; underdevelopment of the venture industry; lack of incentive mechanisms for technology transfer; weakness of the subsystem for the protection of intellectual property rights. Addressing these issues requires improving state policy in the field of technology transfer and includes regulatory, economic and organizational groups of measures. Further research is related to the study and consideration of the possibilities of using foreign experience to stimulate technology transfer in the domestic economy. The transfer of the technological capabilities requires knowledge of the design capabilities and features of equipment and products, the choice of personnel capable of managing and taking into account the many cultural influences on personnel relations within the technology source company with the recipient company.

\section{References:}

1. Melnik A.O. (2012) Adaptazia vitchiznyanih pidpriemstv v umovah svitovoi ekonomichnoi krizi [Adaptation of domestic enterprises in the conditions of the world economic crisis]. Business-Inform, vol. 12, pp. 30-32.

2. Mikityk P.P. (2015) Inovaziiniy rozvitok pidpriemstva [Innovative development of the enterprise]. Ternopil : Printep-Inform. (in Ukrainian)

3. The law of Ukraine (2002) Pro inovaziinu diyalnist [Innovative activity]. Information of the Supreme Soviet of Ukraine, vol. 36, pp. 266.

4. Melnik A.O. (2014) Switovi ekonomichni krizi v ekonomitsi Ukraini ta Ih naslidki [World economic crises in the economy of Ukraine and their consequences]. Global and national economic problems, vol. 2, pp. 108-113.

5. Melnik A.O. (2004) Ekonomicna adaptazia pidpriemstv u mehanizmi pidvischenya ih konkurentnozdatnodsti [Economic adaptation of enterprises in the mechanism of increasing their competitiveness]. Bulletin of the Technological University of Podillya, vol. 6, pp. 206-211.

6. The Global Competitivness Report. URL: http://www.weforum.org/ issues/global-competitiveness (accessed 25 September 2020).

7. Global innovation index. URL: http://www.globalinnovationindex.org. 11. Proposed Standard Method of Compiling and Interpreting Technology Balance of Payments Data (accessed 25 September 2020).

8. Malitski B.A. (2000) Naukovo-technicniy potenzial Ukraini: stan, problem, perspective rozvitku [Scientific and technical potential of Ukraine: state, problems, prospects of development]. Center for Research of Scientific and Technical Potential and History of Science. GN Dobpova NAS of Ukraine.

9. Analytical reference (2014) Stan rozvitku nauki I tehniki, resultat naukovoi, naukovo-tehnichnoi, innovaziinoi diyalnosti, transferu tehnologiy za 2013 rik [State of development of science and technology, results of scientific, scientific-technical, innovative activity, technology of technology 2013]. State Agency for Science, Innovation and Informatization of Ukraine, pp. 180.

10. Mulyakova-Bochi A.K. (2012) Formuvania ta ozinka tehnologichnogo platiznogo balansu Ukraini v konteksti inovaziinogo rozvitku [Formation and assessment of the technological balance of payments of Ukraine in the context of innovation development]. URL: http://archive.nbuv.gov.ua/e-journals/ eui/2012_1/PDF/12makkir.pdf (accessed 25 September 2020).

11. URL:https://zn.ua/ukr/EDUCATION/naukovo-tehnologichniy_rozvitok_ukrayini_za_umov_svitovoyi_globalizatsiyi.html(accessed 25 September 2020).

12. Approval of the Strategy for the Development of Innovative Activities for the period up to 2030. URL: https://zakon.rada.gov.ua/ laws/show/526-2019- \%D1\%80 (accessed 25 September 2020).

Список використаних джерел:

1. Мельник А. О. Адаптація вітчизняних підприємств в умовах світової економічної кризи. Бізнес-Інформ. 2012. C. $30-32$. 
2. Микитюк П. П. Інноваційний розвиток підприємства. Навчальний посібник. Тернопіль: ПП «Принтер Інформ», 2015. $224 \mathrm{c}$.

3. Про інноваційну діяльність: закон України. Відомості Верховної Ради України (ВВР). 2002. № 36. Ст. 266. Із змінами та доповненнями.

4. Мельник А.О. Світові економічні кризи в економіці України та їх наслідки. Глобальні та національні проблеми економіки. 2014. Вип. 2. С. 108-113.

5. Мельник А.О. Економічна адаптація підприємств у механізмі підвищення їх конкурентоздатності. Вісник Технологічного університету Поділля. 2004. № 6. С. 206-211.

6. The Global Competitivness Report. URL: http://www.weforum.org/issues/global-competitiveness (дата 3вернення: 30.09.2020).

7. Global innovation index. URL: http://www.globalinnovationindex.org. 11. Proposed Standard Method of Compiling and Interpreting Technology Balance of Payments Data (дата звернення: 25.09.2020).

8. Науково-технічний потенціал України: стан, проблеми, перспективи розвитку /за ред. Б.А. Малицького : Київ: Центр досліджень науково-технічного потенціалу та історії науки ім. Г.Н. Доброва НАН України, 2000.

9. Аналітична довідка «Стан розвитку науки і техніки, результати наукової, науково-технічної, інноваційної діяльності, трансферу технологій за 2013 рік». Державне агентство з питань науки, інновацій та інформатизації України. Київ. 2014. 180 c. URL: http://old.dknii.gov. ua/?q=system/files/sites/default/files/images/_за_2013_сокр_ок\%2B.pdf(дата звернення: 25.09.2020).

10. Мулякова-Бочі А. К. Формування та оцінка технологічного платіжного балансу України в контексті інноваційного розвитку. URL: http://archive.nbuv.gov.ua/e-journals/ eui/2012_1/PDF/12makkir.pdf (дата звернення: 25.09.2020).

11. URL: https://zn.ua/ukr/EDUCATION/naukovo-tehnologichniy_rozvitok_ukrayini_za_umov_svitovoyi_globalizatsiyi.html (дата звернення: 25.09.2020).

12. Про схвалення Стратегії розвитку сфери інноваційної діяльності на період до 2030 року. URL : https://zakon.rada.gov.ua/ laws/show/526-2019- \%D1\%80 (дата звернення: 25.09.2020).

Мельник А.О., Будякова О.Ю., Кісільов В.П. Київський національний університет технологій та дизайну

\section{ОСОБЛИВОСТІ ТРАНСФЕРУ ТЕХНОЛОГІЙ В УМОВАХ ІНТЕГРАЦЇ̈}

Економіка найбільш розвинених держав орієнтується на інноващії. Розвиток технологій, в розвинених індустріальних $і$ особливо - постіндустріальних суспільствах відіграє важливу роль. У сучасних умовах розвитку економіки розвинуті країни, де наука виконує роль головного економіко-відтворювального фактора, забезпечують свій розвиток за рахунок вдосконалення існуючих технологій. Можливість міжнародної співпраці по технологічному обміну та трансфер інтелектуального потенціалу - одна з ознак економічного прогресу краӥн. Приєднання Украӥни до європейських та світових інтеграційних проиесів неможливе без врахування геополітичного чинника, щуо значною мірою визначається сьогоднішнім станом економіки Украӥни та ї̈ подальшим розвитком. У статті розглядаються можливості та перспективи інноваційного розвитку украйнських підприємств. Об'єктом иьього дослідження є трансфер технологій в Україні, а також ступінь їі впливу на сталий розвиток економіки украӥнських підприємств. Перед керівниитвом підприємств стоїть пріоритетне, важливе завдання: переведення промисловості на рейки інноваційної, високотехнологічної, конкурентоспроможної економіки. Сьогодні підприємства нашої країни намагаються зменшити технологічний розрив з провідними країнами, але ступінь відсталості вітчизняної економіки залишається досить високою. У сучасних умовах для швидкого зростання економіки інтеграчійної освіти необхідно розвивати власну галузь на основі найсучасніших, сучасних, унікальних технологій - завдяки їм можна створити максимальну додану вартість, забезпечуючи тим самим конкурентну перевагу для виробництво. Однак галузь високих технологій стикається з низкою гострих проблем, які потребують негайного вирішення. Проаналізовані основні показники участі Украӥни в міжнародному трансфері технологій. Визначені основні чинники, які перешкоджають посиленню інтеграції вітчизняної економіки у світові ринки технологій. Сформовані пропозиції по інтенсифікації трансферу технологій в Украӥні, які об'єднані в нормативно-правові, економічні і організаційні групи. Перед високотехнологічної галуззю стоїть ряд гострих проблем, які потребують негайного вирішення.

Ключові слова: трансфер технологій, науково-технічне співробітництво, інноваційна економіка, міжнародна інтеграція, наџіональна інноваційна система. 